\title{
Estimated nationwide impact of implementing a preemptive pharmacogenetic panel approach to guide drug prescribing in primary care in The Netherlands
}

\author{
P. C. D. Bank, J. J. Swen * and H. J. Guchelaar
}

\begin{abstract}
Background: Pharmacogenetics (PGX) is currently implemented in hospitals to optimize therapy with high-risk drugs. However, many drugs with dosing recommendations from the Dutch Pharmacogenetics Working Group and the Clinical Pharmacogenetics Implementation Consortium are used in primary care. Actionable phenotypes for the genes covered in these guidelines are common with estimates ranging from 85 to $95 \%$ of the population carrying at least one actionable phenotype. The goal of this study was to estimate the clinical impact of implementation of an upfront panel-based pharmacogenetic screening for eight genes related to drugs used in primary care for 2016.

Methods: For this study, dispensing data concerning first prescription for the period January 1-December 31, 2016, were combined with frequency data obtained in the "Implementation of Pharmacogenetics into Primary Care Project" (IP3) study to estimate the occurrence of actionable gene-drug pairs in daily practice in community pharmacies.

Results: In $23.6 \%$ of all new prescriptions of 45 drugs ( $n=856,002$ new prescriptions/year), an actionable gene-drug interaction (GDI) was present according to the guidelines of the Dutch Pharmacogenetics Working Group. More importantly, these GDls would result in a dose adjustment or switch to another drug in $5.4 \%$ of all new prescriptions.
\end{abstract}

Conclusions: Consequently, with an anticipated near future where healthcare professionals will be regularly confronted with PGx test results, adjusting pharmacotherapy based on this information will become a routine task in healthcare.

Keywords: Pharmacogenetics, Pharmacogenomics, Clinical practice, General practice, Community pharmacy

\section{Introduction}

The current use of prescription drugs is suboptimal. Many patients suffer from poor drug efficacy which in turn can lead to cessation of therapy or disease progression. Another significant portion of patients experience serious drug adverse events with possible hospitalization or even death as a result of the current one-size-fits-all approach $[1,2]$. In recent decades, it has become clear that the interpatient variability in drug efficacy and toxicity can be (partially) explained by genetic variation

\footnotetext{
* Correspondence: j.j.swen@lumc.nl

Department of Clinical Pharmacy and Toxicology, Leiden University Medical Center, P.O Box 9600, 2300 RC Leiden, The Netherlands
}

between individuals [3, 4]. Therefore, in 2005, the Royal Dutch Pharmacists Association formed the Dutch Pharmacogenetics Working Group (DPWG) to aid in the personalization of pharmacotherapy based on an individual's genetic makeup. The DPWG has created a set of evidence-based guidelines $(n=86)$ which have been fully integrated into the electronic drug prescribing and dispensing systems and are available through clinical decision support [5-7]. Currently, in The Netherlands, pharmacogenetics (PGx) testing is mostly performed for single gene-drug pairs. For example, testing for DPYD before starting therapy with capecitabine or 5 -fluorouracil is routine care in The Netherlands and supported by a

(c) The Author(s). 2019 Open Access This article is distributed under the terms of the Creative Commons Attribution 4.0 International License (http://creativecommons.org/licenses/by/4.0/), which permits unrestricted use, distribution, and reproduction in any medium, provided you give appropriate credit to the original author(s) and the source, provide a link to the Creative Commons license, and indicate if changes were made. The Creative Commons Public Domain Dedication waiver (http://creativecommons.org/publicdomain/zero/1.0/) applies to the data made available in this article, unless otherwise stated. 
consistent body of evidence [8-10]. The impact of PGx in this drug-gene combination is considered high as DPD-deficient patients receiving a normal dose of capecitabine have a high risk for severe toxicities [8]. Nowadays, genotyping platforms allow for simultaneous characterization of multiple genes. This approach has been evaluated in multiple studies in secondary centers [11-16]. Results indicate that $>95 \%$ of all individuals carry at least one actionable phenotype when tested for a panel of up to 12 genes (including, e.g., CYP2C9, CYP2C19, CYP2D6, SLCO1B1, and VKORC1) [17-19]. This panel-based approach has also been favorably evaluated in a number of small pilot studies in a primary care setting [20-22].

Most drugs frequently prescribed in primary care are not considered high risk. However, the combination of a high prescription volume and a high frequency of actionable phenotypes of the associated genes may also have resulted in a high total impact on the population of patients [23, 24]. In this study, we set out to make a quantitative estimate of the potential impact of implementing PGx in primary care by calculating the number of new prescriptions in The Netherlands that comprise a gene-drug pair that is considered actionable by the DPWG. Additionally, we investigated the frequency of prescriptions where a change in choice of drug or dosage would have been required at the start of therapy as described in the guidelines of the DPWG based on a prediction of their genetic predicted phenotype.

\section{Methods}

\section{Selection of drug-gene interactions and classification of} therapeutic recommendations

The methodology for guideline development of the DPWG has been described in detail previously [5-7]. For this study, the DPWG guidelines were reviewed for drugs with an actionable therapeutic recommendation for a least one phenotype. Therapeutic recommendations were classified in no action, lower dose, higher dose, alternate drug, additional clinical monitoring of the patient, optional lower dose, optional higher dose, and a maximum dose threshold. Additionally, the guidelines were checked to see whether the therapeutic recommendations were dependent on patient characteristics such as age and concomitant use of other medication. For citalopram and escitalopram, the therapeutic recommendations are dependent on the age of the patient as a lower dose is recommended for patients $\geq 65$ years of age $[5,6,25]$. Secondly, for SLCO1B1 and atorvastatin, the therapeutic recommendation depends on concomitant use of a CYP3A4 inhibiting drug, i.e., amiodarone, verapamil, or diltiazem. Patients with a SLCO1B1 521TC or CC genotype and a CYP3A4 inhibitor are advised to switch to rosuvastatin or pravastatin, whereas in patients without a CYP3A4 inhibitor only increased monitoring for muscle pain is recommended.

\section{Source of nationwide prescription data}

The Foundation of Pharmaceutical Statistics (Stichting Farmaceutische Kengetallen, SFK) collects data on dispensed drugs from $\sim 95 \%$ of all the community pharmacies in The Netherlands [26]. To this end, patients are assigned an anonymous identification number that allows tracking within the participating community pharmacies [26]. To this end, patients are assigned an anonymous identification number that allows tracking within the participating community pharmacies [26]. For this study, dispensing data concerning first prescription for the period January 1-December 31, 2016, were obtained. First prescriptions in The Netherlands are defined by healthcare insurers as the dispensing of a drug that has not been used by the patient in the prior 365 days. For citalopram, escitalopram, and atorvastatin, additional information concerning age, and concomitant medication of the patients were also collected $[5,6,25]$.

\section{Frequencies of genetic predicted phenotypes}

To estimate the potential clinical impact of implementation of preemptive testing for a panel consisting of 8 genes (CYP2C9, CYP2C19, CYP2D6, CYP3A5, $D P Y D, S L C O 1 B 1, T P M T$, and VKORC1) related to drugs used in primary care, frequency data obtained in the "Implementation of Pharmacogenetics into Primary Care Project" (IP3) study were used as a representation of the Dutch population [24]. In short, for the IP3 study, 200 patients receiving a new prescription for a selection of 10 drugs with a known gene-drug interaction were genotyped for a panel of 8 genes and 40 genetic variants (see Additional file 1) using the Affymetrix Drug Metabolism Enzymes and Transporters (DMET) platform supplemented with a RT-PCR Taqman assay to determine the CYP2D6 copy-number variation $(\mathrm{CNV})$. The genetic test results were translated to actionable phenotypes (e.g., extensive/normal, intermediate, poor, or ultra-rapid metabolizer or EM, IM, PM, and UM respectively) according to the interpretation tables provided by the DPWG guidelines, and communicated to the general practitioner and pharmacist to perform genotype-guided dosing using clinical decision support [24]. A comparison to the Genome Of the NetherLands (GONL) dataset, containing 250 Dutch parent-offspring families, showed similar minor allele frequencies (MAF) for the selection of SNPs tested in the IP3 study. Similarly, the MAFs of the SNPs in the Caucasian subpopulation in the IP3 study was comparable to the 
European non-Finnish population in the gnomAD database. Furthermore, specifically for $C Y P 2 D 6$, similar frequencies of genetic predicted phenotypes were recently reported by compiling data from the Clinical Pharmacogenetics Implementation Consortium (CPIC) guidelines [27]. All these comparisons show that the population of patients in the IP3 study reflect the ethnic composition of the population in The Netherlands and the study population is a representative sample of the Dutch population [28, 29]. Additionally, the percentage of patients with at least one genetic variant in the tested multigene panel was comparable to previously reported PGx implementation projects [12, 14, 17-19].

\section{Estimating the clinical impact of PGx in primary care}

Frequencies of actionable phenotypes for the eight genes from the IP3 were inferred for the Dutch population. Following this comparison, the genetic data were combined with the prescription data obtained from the SFK. After exclusion of drugs not approved in The Netherlands (warfarin) or primarily used in secondary care (5-fluorouracil, capecitabine, and tegafur), a selection of 45 drugs remained (see Table 1). This final selection was used to estimate the occurrence of actionable gene-drug pairs in daily practice in community pharmacies by multiplying the estimated frequency of actionable phenotypes for each gene with the observed first prescriptions of the related drugs (see Table 2).

\section{Results}

For this analysis, prescription data for the selection of 45 drugs were available from 1882 pharmacies $(94.4 \%$ of total). In 2016, a total of 3,338,464 unique patients received a total of $3,628,597$ new prescriptions for the selected 45 drugs (see Table 1). The distribution of the phenotypes for the eight genes is presented in Fig. 1. Based on the frequencies of the actionable phenotypes of the eight genes and the amount of 3,628,597 first prescriptions, it can be estimated that in 856,002 new prescriptions $(23.6 \%)$ a gene-drug pair is present (see Table 2). In 195,691 new prescriptions $(=5.4 \%)$, the gene-drug pair requires an action by the prescribing physician or dispensing pharmacists. These actions include lowering the dose $(n=43,616)$, increasing the dose $(n=1315)$, or switching to an alternate drug $(n=$ $150,761)$ as per the recommendations of the DPWG. For the remainder of the prescriptions where an actionable gene-drug pair is present $(n=660,311)$, no direct action is required; however, more intensified monitoring for side effects is recommended $(n=250,980)$, guarding a lower maximum threshold of the prescribed dose designated by the DPWG for specific phenotypes $(n=26,924)$ or a potential decrease $(n=90,543)$ or increase $(n=$
$291,863)$ of the dose in case of observed over- or undertreatment respectively (see Table 2).

In case all patients treated in primary care received pre-emptive screening for the panel of eight genes, $\sim 54$ per 1000 first prescriptions would have required an intervention for the selected 45 drugs.

Additionally, healthcare professionals would be required to monitor patients more intensively for side effects or failure of treatment in 236 per 1000 first prescriptions of the drugs included in the selection.

This results in a calculated number needed to genotype of 19 for a required intervention on a first time prescription by a healthcare professional at the start of therapy for this selection of 45 drugs. Of note, this calculated number needed to genotype is likely a conservative estimate as interventions for gene-drug interactions (23.6\%) of the "monitor closely" type were not used to calculate the number needed to genotype as it is currently unknown how many interventions are performed in this type of gene-drug interaction.

\section{CYP2C19 and (es)citalopram}

For the selective serotonin reuptake inhibitors (SSRI) citalopram, escitalopram, and sertraline, the DPWG has provided a lower maximum dose for intermediate and poor metabolizers compared to extensive/normal metabolizers $[5,6,25]$. However, in contrast to sertraline, the maximum dosages for citalopram and escitalopram have alternate thresholds for patients $<65$ years of age vs. $\geq 65$ years. For example, for a patient with a first prescription for citalopram with a poor metabolizer phenotype $<65$ years, the advised maximum daily dose is $20 \mathrm{mg} /$ day, whereas for a patient $\geq 65$ years with the same phenotype the advised maximum daily dose is $10 \mathrm{mg} /$ day.

In 41,338 of the 56,580 new prescriptions for citalopram $(=73.1 \%)$, the patient was below the age of 65 whereas in 15,424 cases the patient was 65 years or older $(=26.9 \%)$. From these data, it can be inferred that in 8888 prescriptions, a patient with an IM phenotype of age under 65 should have received a dose restriction of $30 \mathrm{mg}$ and in 3277 prescriptions a patient with an IM phenotype of age $65+$ should have been restricted to a maximum dose of $15 \mathrm{mg}$. For PMs, the dose should have been maximized to $20 \mathrm{mg}$ in individuals of $<65$ years old ( $n=1240$ prescriptions) and $10 \mathrm{mg}$ for age $65+(n=457$ prescriptions) respectively.

In case of escitalopram, the dose restriction should have been $15 \mathrm{mg}$ ( $n=4607$ prescriptions) and $7.5 \mathrm{mg}(n=651$ prescriptions) for patients with the IM phenotype in the groups $<65$ and $\geq 65$ respectively. In case of 643 patients younger than 65 years of age with the PM phenotype, the dose should have been restricted to $10 \mathrm{mg}$, whereas in 91 patients of $\geq 65$ years with the same inferred phenotype the dose should have been restricted to $5 \mathrm{mg}$ (see Table 2). 
Table 1 Number of incident prescriptions in 2016. An overview of the total number of new prescriptions for drugs with an actionable DPWG recommendation dispensed in Dutch pharmacies in 2016 that supply data to the SFK sorted to drug name

\begin{tabular}{|c|c|c|}
\hline ATC & Drug name & No. of first-time prescriptions \\
\hline B01AA07 & ACENOCOUMAROL & 49,934 \\
\hline N06AA09 & AMITRIPTYLINE & 98,750 \\
\hline N05AX12 & ARIPIPRAZOLE & 13,869 \\
\hline N06BA09 & ATOMOXETINE & 1987 \\
\hline C10AA05 & ATORVASTATIN & 111,840 \\
\hline C10BA05 & ATORVASTATIN AND EZETIMIBE & 1909 \\
\hline L04AX01 & AZATHIOPRINE & 6943 \\
\hline N06AB04 & CITALOPRAM & 56,580 \\
\hline N06AA04 & CLOMIPRAMINE & 7079 \\
\hline B01AC04 & CLOPIDOGREL & 98,709 \\
\hline R05DA04 & CODEINE & 519,728 \\
\hline N02AJ06 & CODEINE AND PARACETAMOL & 69,300 \\
\hline N06AA12 & DOXEPIN & 270 \\
\hline N06AB10 & ESCITALOPRAM & 24,454 \\
\hline A02BC05 & ESOMEPRAZOLE & 65,370 \\
\hline B01AA04 & FENPROCOUMON & 12,621 \\
\hline N03AB02 & FENYTOINE & 828 \\
\hline C01BC04 & FLECAINIDE & 13,605 \\
\hline N05AD01 & HALOPERIDOL & 51,217 \\
\hline N06AA02 & IMIPRAMINE & 988 \\
\hline A02BC03 & LANSOPRAZOLE & 1536 \\
\hline L01BB02 & MERCAPTOPURINE & 2598 \\
\hline C07AB02 & METOPROLOL & 194,724 \\
\hline C07BB02 & METOPROLOL MET THIAZIDE & 1908 \\
\hline M01AE52 & NAPROXEN AND ESOMEPRAZOLE & 673 \\
\hline N06AA10 & NORTRIPTYLINE & 20,717 \\
\hline A02BC01 & OMEPRAZOLE & 575,353 \\
\hline N02AA05 & OXYCODONE & 464,799 \\
\hline N02AA55 & OXYCODONE AND NALOXONE & 82 \\
\hline $\mathrm{A} 02 \mathrm{BC} 02$ & PANTOPRAZOLE & 361,741 \\
\hline A02BD04 & PANTOPRAZOLE, AMOXICILLINE, AND CLARITROMYCINE & 21,768 \\
\hline N06AB05 & PAROXETINE & 27,018 \\
\hline N05AG02 & PIMOZIDE & 1060 \\
\hline C01BC03 & PROPAFENON & 409 \\
\hline N06AB06 & SERTRALINE & 28,861 \\
\hline C10AA01 & SIMVASTATIN & 187,362 \\
\hline $\mathrm{C} 10 \mathrm{BA} 02$ & SIMVASTATIN AND EZETIMIBE & 4888 \\
\hline L04AD02 & TACROLIMUS & 2722 \\
\hline L02BA01 & TAMOXIFEN & 10,807 \\
\hline L01BB03 & TIOGUANINE & 1883 \\
\hline N02AX02 & TRAMADOL & 357,389 \\
\hline N02AJ13 & TRAMADOL AND PARACETAMOL & 124,951 \\
\hline N06AX16 & VENLAFAXINE & 26,603 \\
\hline
\end{tabular}


Table 1 Number of incident prescriptions in 2016. An overview of the total number of new prescriptions for drugs with an actionable DPWG recommendation dispensed in Dutch pharmacies in 2016 that supply data to the SFK sorted to drug name (Continued)

\begin{tabular}{lll}
\hline ATC & Drug name & No. of first-time prescriptions \\
\hline J02AC03 & VORICONAZOLE & 891 \\
N05AF05 & ZUCLOPENTHIXOL & 1873 \\
\hline
\end{tabular}

\section{SLCO1B1 and atorvastatin}

The frequency of patients with a reduced transport capacity mediated as a result of genetic variation in the SLCO1B1 gene was found to be $25.5 \%$ of which $23.5 \%$ was the result of the $521 \mathrm{~T} / \mathrm{C}$ genotype and $2.0 \%$ the result of a $521 \mathrm{C} / \mathrm{C}$ genotype. In 2016, a total of 113,749 first prescriptions for atorvastatin or atorvastatin combined with ezetimibe were dispensed. Based on the sample of genotype data from the IP3 study, we extrapolated that in 29,006 prescriptions the patient would likely carry the $521 \mathrm{~T} / \mathrm{C}$ or the $521 \mathrm{C} / \mathrm{C}$ genotype. For these individuals, an additional check for concomitant use of inhibitors of CYP3A4 is required as per the DPWG guidelines and in case of the presence of a CYP3A4 inhibitor healthcare professionals are recommended to switch to an alternate drug.

\section{Discussion}

This study provides an estimate of the potential nationwide clinical impact of a pre-emptive pharmacogenetic panel approach in primary care in The Netherlands. Based on frequencies of actionable phenotypes gathered in a pilot study of 200 patients and nationwide prescription data $(n=3,628,597)$, we inferred that in $23.6 \%$ of the first prescriptions of the selected 45 drugs a gene-drug pair is present [24]. If pre-emptive genetic testing of the panel consisting of eight genes had been performed in this population, we estimate that $5.4 \%$ of the new prescriptions an intervention at the start of therapy would have been required and in $18.2 \%$ of the new prescriptions the therapeutic recommendations of the DPWG advise more intense clinical monitoring of the patient with an optional dose adjustment in case of suboptimal therapy. An example of such a recommendation is the optional increase in dose of a proton pump inhibitor in a CYP2C19 ultra-rapid metabolizer.

A strength of this study is that the dataset used to calculate the frequency of gene-drug pairs compasses 1882 pharmacies $(94.4 \%$ of total) and reflects all community pharmacies in The Netherlands [26]. This allows for a detailed view of the medication use of the total population treated in primary care and provides accurate data of the number of first prescriptions of one of the PGx drugs where patients have not yet reached their maintenance therapy as a result of empirical dosing by general practitioners. In a similar study by Samwald et al., prescription data from a combination of sources (private insurance, Medicaid or Medicare) were used [30]. Whereas the dataset used in that study encompasses a considerable larger number of patients, it is at risk for selection bias as it is restricted to selected groups within the population of the USA [30].

Although the data in this analysis encompasses $94.4 \%$ of the pharmacies in The Netherlands and provides a detailed view of drug use in primary care, other sections of pharmaceutical care are not represented in this dataset. A majority of the $5.6 \%$ of pharmacies that do not supply data to the database of the SFK are mainly outpatient pharmacies (community pharmacies as part of a hospital). In comparison with community pharmacies, the outpatient pharmacies often dispense more specialized pharmacotherapy, for example HIV therapy. For example, this may result in a higher frequency of drug-drug interactions through CYP3A4 and higher frequency of relevant drug-drug-gene interactions for statins. The number of first prescriptions where a patient uses a CYP3A4 inhibitor may likely be an underestimation of the reality.

Another limitation to this study is the lack of complete clinical data (such as comorbidities, reduced clearance of drugs, and information on indications) in the available dataset. For a limited number of gene-drug interactions, the therapeutic recommendation of the DPWG is co-dependent on these clinical data and co-medication. Unfortunately, our dataset only contained information about age, gender, and co-medication with CYP3A4 inhibitors. As a result, estimates for gene-drug interaction requiring interpretation of additional clinical factors or information about indication to support decision making might differ from reality. For example, in case of the interaction of simvastatin and the SLCO1B1 521TC genotype, the primary recommendation is to switch to an alternate therapy (used in this analysis to infer therapeutic interventions). However, if the prescribed dose is $\leq 40 \mathrm{mg}$ simvastatin, the recommendation is to continue simvastatin provided the patient carries no additional risk for statin-induced myopathy. Additional risk factors include hepatic or renal impairment, co-medication with CYP3A4 inhibitors, co-medication with SLCO1B1 inhibitors, female gender, old age ( $\geq 65)$ or hypothyroidism $[7$, 25 ]. To estimate the potential impact of clinical factors on the number of patients requiring an intervention, we 
Table 2 Overview of inferred gene-drug pairs sorted per gene. An overview of the estimates of the occurrences of gene-drug pairs among 45 drugs frequently prescribed in primary care

\begin{tabular}{|c|c|c|c|c|}
\hline Drug & $\begin{array}{l}\text { Count incident } \\
\text { prescriptions (total) }\end{array}$ & $\begin{array}{l}\text { Actionable } \\
\text { phenotype }\end{array}$ & $\begin{array}{l}\text { Count incident } \\
\text { prescriptions }\end{array}$ & $\begin{array}{l}\text { Type of therapeutic } \\
\text { recommendation }\end{array}$ \\
\hline \multicolumn{5}{|l|}{ CYP2C9 } \\
\hline \multirow[t]{3}{*}{ PHENYTOIN* } & \multirow[t]{3}{*}{828} & EM & 518 & No action \\
\hline & & IM & 294 & Lower dose required at start therapy \\
\hline & & PM & 17 & Lower dose required at start therapy \\
\hline \multicolumn{5}{|l|}{ CYP2C19 } \\
\hline \multirow[t]{4}{*}{ CITALOPRAM $<65$ years $^{*}$} & \multirow[t]{4}{*}{41,338} & EM & 29,557 & No action \\
\hline & & IM & 8,888 & Guard maximum daily dose \\
\hline & & PM & 1240 & Guard maximum daily dose \\
\hline & & UM & 1654 & No action \\
\hline \multirow[t]{4}{*}{ CITALOPRAM $\geq 65$ years $^{*}$} & \multirow[t]{4}{*}{15,242} & EM & 10,898 & No action \\
\hline & & IM & 3277 & Guard maximum daily dose \\
\hline & & PM & 457 & Guard maximum daily dose \\
\hline & & UM & 610 & No action \\
\hline \multirow[t]{4}{*}{ CLOPIDOGREL $^{*}$} & \multirow[t]{4}{*}{98,709} & EM & 70,577 & No action \\
\hline & & IM & 21,222 & $\begin{array}{l}\text { Switch to alternate drug at start } \\
\text { therapy }\end{array}$ \\
\hline & & PM & 2961 & $\begin{array}{l}\text { Switch to alternate drug at start } \\
\text { therapy }\end{array}$ \\
\hline & & UM & 3948 & Observe status of patient carefully \\
\hline \multirow[t]{4}{*}{ ESCITALOPRAM $<65$ years $^{*}$} & \multirow[t]{4}{*}{21,427} & EM & 15,320 & No action \\
\hline & & IM & 4607 & Guard maximum daily dose \\
\hline & & PM & 643 & Guard maximum daily dose \\
\hline & & UM & 857 & No action \\
\hline \multirow[t]{4}{*}{ ESCITALOPRAM $\geq 65$ years $^{*}$} & \multirow[t]{4}{*}{3027} & EM & 2164 & No action \\
\hline & & IM & 651 & Guard maximum daily dose \\
\hline & & PM & 91 & Guard maximum daily dose \\
\hline & & UM & 121 & No action \\
\hline \multirow[t]{4}{*}{ ESOMEPRAZOLE } & \multirow[t]{4}{*}{65,370} & EM & 46,740 & No action \\
\hline & & IM & 14,055 & No action \\
\hline & & PM & 1961 & No action \\
\hline & & UM & 2615 & Optional increase of dose \\
\hline \multirow[t]{4}{*}{ ESOMEPRAZOLE AND NAPROXEN } & \multirow[t]{4}{*}{673} & EM & 481 & No action \\
\hline & & IM & 145 & No action \\
\hline & & PM & 20 & No action \\
\hline & & UM & 27 & Optional increase of dose \\
\hline \multirow[t]{4}{*}{ LANSOPRAZOLE } & \multirow[t]{4}{*}{1536} & EM & 1098 & No action \\
\hline & & IM & 330 & No action \\
\hline & & PM & 46 & No action \\
\hline & & UM & 61 & Optional increase of dose \\
\hline \multirow[t]{4}{*}{ OMEPRAZOLE } & \multirow[t]{4}{*}{575,353} & EM & 411,377 & No action \\
\hline & & IM & 123,701 & No action \\
\hline & & PM & 17,261 & No action \\
\hline & & UM & 23,014 & Optional increase of dose \\
\hline
\end{tabular}


Table 2 Overview of inferred gene-drug pairs sorted per gene. An overview of the estimates of the occurrences of gene-drug pairs among 45 drugs frequently prescribed in primary care (Continued)

\begin{tabular}{|c|c|c|c|c|}
\hline Drug & $\begin{array}{l}\text { Count incident } \\
\text { prescriptions (total) }\end{array}$ & $\begin{array}{l}\text { Actionable } \\
\text { phenotype }\end{array}$ & $\begin{array}{l}\text { Count incident } \\
\text { prescriptions }\end{array}$ & $\begin{array}{l}\text { Type of therapeutic } \\
\text { recommendation }\end{array}$ \\
\hline \multirow[t]{4}{*}{ PANTOPRAZOLE } & \multirow[t]{4}{*}{361,741} & EM & 258,645 & No action \\
\hline & & $\mathrm{IM}$ & 77,774 & No action \\
\hline & & PM & 10,852 & No action \\
\hline & & UM & 14,470 & Optional increase of dose \\
\hline \multirow[t]{4}{*}{ PANTOPAC } & \multirow[t]{4}{*}{21,768} & EM & 15,564 & No action \\
\hline & & IM & 4680 & No action \\
\hline & & PM & 653 & No action \\
\hline & & UM & 871 & Higher dose required at start therapy \\
\hline \multirow[t]{4}{*}{ SERTRALINE ${ }^{*}$} & \multirow[t]{4}{*}{28,861} & EM & 20,636 & No action \\
\hline & & IM & 6205 & Guard maximum daily dose \\
\hline & & PM & 866 & Guard maximum daily dose \\
\hline & & UM & 1154 & No action \\
\hline \multirow[t]{4}{*}{ VORICONAZOLE } & \multirow[t]{4}{*}{891} & EM & 637 & No action \\
\hline & & IM & 192 & Observe status of patient carefully \\
\hline & & PM & 27 & Observe status of patient carefully \\
\hline & & UM & 36 & Higher dose required at start therapy \\
\hline \multicolumn{5}{|l|}{ CYP2D6 } \\
\hline \multirow[t]{4}{*}{ AMITRIPTYLINE ${ }^{*}$} & \multirow[t]{4}{*}{98,750} & EM & 52,338 & No action \\
\hline & & IM & 39,994 & $\begin{array}{l}\text { Switch to alternate drug at start } \\
\text { therapy }\end{array}$ \\
\hline & & PM & 4938 & $\begin{array}{l}\text { Switch to alternate drug at start } \\
\text { therapy }\end{array}$ \\
\hline & & UM & 1481 & $\begin{array}{l}\text { Switch to alternate drug at start } \\
\text { therapy }\end{array}$ \\
\hline \multirow[t]{4}{*}{ ARIPIPRAZOLE } & \multirow[t]{4}{*}{13,869} & EM & 7351 & No action \\
\hline & & IM & 5617 & No action \\
\hline & & PM & 693 & Guard maximum daily dose \\
\hline & & UM & 208 & No action \\
\hline \multirow[t]{4}{*}{ ATOMOXETINE } & \multirow[t]{4}{*}{1987} & EM & 1053 & No action \\
\hline & & IM & 805 & Optional decrease of dose \\
\hline & & PM & 99 & Optional decrease of dose \\
\hline & & UM & 30 & Observe status of patient carefully \\
\hline \multirow[t]{4}{*}{ CLOMIPRAMINE ${ }^{*}$} & \multirow[t]{4}{*}{7079} & EM & 3752 & No action \\
\hline & & IM & 2867 & Lower dose required at start therapy \\
\hline & & PM & 354 & Lower dose required at start therapy \\
\hline & & UM & 106 & $\begin{array}{l}\text { Switch to alternate drug at start } \\
\text { therapy }\end{array}$ \\
\hline \multirow[t]{4}{*}{ CODEINE $^{*}$} & \multirow[t]{4}{*}{519,728} & EM & 275,456 & No action \\
\hline & & IM & 210,490 & No action \\
\hline & & PM & 25,986 & No action \\
\hline & & UM & 7796 & $\begin{array}{l}\text { Switch to alternate drug at start } \\
\text { therapy }\end{array}$ \\
\hline \multirow[t]{2}{*}{ CODEINE AND PARACETAMOL ${ }^{*}$} & \multirow[t]{2}{*}{69,300} & EM & 36,729 & No action \\
\hline & & IM & 28,067 & Optional increase of dose \\
\hline
\end{tabular}


Table 2 Overview of inferred gene-drug pairs sorted per gene. An overview of the estimates of the occurrences of gene-drug pairs among 45 drugs frequently prescribed in primary care (Continued)

\begin{tabular}{|c|c|c|c|c|}
\hline Drug & $\begin{array}{l}\text { Count incident } \\
\text { prescriptions (total) }\end{array}$ & $\begin{array}{l}\text { Actionable } \\
\text { phenotype }\end{array}$ & $\begin{array}{l}\text { Count incident } \\
\text { prescriptions }\end{array}$ & $\begin{array}{l}\text { Type of therapeutic } \\
\text { recommendation }\end{array}$ \\
\hline & & PM & 3465 & $\begin{array}{l}\text { Switch to alternate drug at start } \\
\text { therapy }\end{array}$ \\
\hline & & UM & 1040 & $\begin{array}{l}\text { Switch to alternate drug at start } \\
\text { therapy }\end{array}$ \\
\hline \multirow[t]{4}{*}{ DOXEPIN ${ }^{*}$} & 270 & EM & 143 & No action \\
\hline & & IM & 109 & Lower dose required at start therapy \\
\hline & & PM & 14 & Lower dose required at start therapy \\
\hline & & UM & 4 & $\begin{array}{l}\text { Switch to alternate drug at start } \\
\text { therapy }\end{array}$ \\
\hline \multirow[t]{4}{*}{ FLECAINIDE } & 13,605 & EM & 7211 & No action \\
\hline & & IM & 5510 & Lower dose required at start therapy \\
\hline & & PM & 680 & Lower dose required at start therapy \\
\hline & & UM & 204 & Observe status of patient carefully \\
\hline \multirow[t]{4}{*}{ HALOPERIDOL } & 51,217 & EM & 27,145 & No action \\
\hline & & IM & 20,743 & No action \\
\hline & & PM & 2561 & Lower dose required at start therapy \\
\hline & & UM & 768 & Optional increase of dose \\
\hline IMIPRAMINE (TOTAL) & 988 & & & \\
\hline \multirow[t]{4}{*}{ IMIPRAMINE (CYP2C19 EM, IM, UM) } & 958 & EM & 508 & No action \\
\hline & & IM & 388 & Lower dose required at start therapy \\
\hline & & PM & 48 & Lower dose required at start therapy \\
\hline & & UM & 14 & $\begin{array}{l}\text { Switch to alternate drug at start } \\
\text { therapy }\end{array}$ \\
\hline \multirow[t]{4}{*}{ IMIPRAMINE (CYP2C19 PM) ${ }^{*}$} & 30 & EM & 16 & Lower dose required at start therapy \\
\hline & & IM & 12 & Lower dose required at start therapy \\
\hline & & PM & 2 & Lower dose required at start therapy \\
\hline & & UM & 0 & $\begin{array}{l}\text { Switch to alternate drug at start } \\
\text { therapy }\end{array}$ \\
\hline \multirow[t]{4}{*}{ METOPROLOL } & 194,724 & EM & 103,204 & No action \\
\hline & & IM & 78,863 & Optional decrease of dose \\
\hline & & PM & 9736 & Optional decrease of dose \\
\hline & & UM & 2921 & Optional increase of dose \\
\hline \multirow[t]{4}{*}{ METOPROLOL AND THIAZIDE } & 1908 & EM & 1011 & No action \\
\hline & & IM & 773 & Optional decrease of dose \\
\hline & & PM & 95 & Optional decrease of dose \\
\hline & & UM & 29 & Optional increase of dose \\
\hline \multirow[t]{4}{*}{ NORTRIPTYLINE* } & 20,717 & EM & 10,980 & No action \\
\hline & & IM & 8390 & Lower dose required at start therapy \\
\hline & & PM & 1036 & Lower dose required at start therapy \\
\hline & & UM & 311 & $\begin{array}{l}\text { Switch to alternate drug at start } \\
\text { therapy }\end{array}$ \\
\hline \multirow[t]{4}{*}{ OXYCODONE } & 464,799 & EM & 246,343 & No action \\
\hline & & IM & 188,244 & Observe status of patient carefully \\
\hline & & PM & 23,240 & Observe status of patient carefully \\
\hline & & UM & 6972 & Observe status of patient carefully \\
\hline
\end{tabular}


Table 2 Overview of inferred gene-drug pairs sorted per gene. An overview of the estimates of the occurrences of gene-drug pairs among 45 drugs frequently prescribed in primary care (Continued)

\begin{tabular}{|c|c|c|c|c|}
\hline Drug & $\begin{array}{l}\text { Count incident } \\
\text { prescriptions (total) }\end{array}$ & $\begin{array}{l}\text { Actionable } \\
\text { phenotype }\end{array}$ & $\begin{array}{l}\text { Count incident } \\
\text { prescriptions }\end{array}$ & $\begin{array}{l}\text { Type of therapeutic } \\
\text { recommendation }\end{array}$ \\
\hline \multirow[t]{4}{*}{ OXYCODONE AND NALOXONE } & 82 & EM & 43 & No action \\
\hline & & IM & 33 & Observe status of patient carefully \\
\hline & & PM & 4 & Observe status of patient carefully \\
\hline & & UM & 1 & Observe status of patient carefully \\
\hline \multirow[t]{4}{*}{ PAROXETINE* } & 27,018 & EM & 14,320 & No action \\
\hline & & IM & 10,942 & No action \\
\hline & & PM & 1351 & No action \\
\hline & & UM & 405 & $\begin{array}{l}\text { Switch to alternate drug at start } \\
\text { therapy }\end{array}$ \\
\hline \multirow[t]{4}{*}{ PIMOZIDE } & 1060 & EM & 562 & No action \\
\hline & & IM & 429 & Lower dose required at start therapy \\
\hline & & PM & 53 & Lower dose required at start therapy \\
\hline & & UM & 16 & No action \\
\hline \multirow[t]{4}{*}{ PROPAFENON } & 409 & EM & 217 & No action \\
\hline & & IM & 166 & Optional decrease of dose \\
\hline & & PM & 20 & Lower dose required at start therapy \\
\hline & & UM & 6 & Observe status of patient carefully \\
\hline \multirow[t]{4}{*}{ TAMOXIFEN ${ }^{*}$} & 10,807 & EM & 5728 & No action \\
\hline & & IM & 4377 & $\begin{array}{l}\text { Switch to alternate drug at start } \\
\text { therapy }\end{array}$ \\
\hline & & PM & 540 & $\begin{array}{l}\text { Switch to alternate drug at start } \\
\text { therapy }\end{array}$ \\
\hline & & UM & 162 & No action \\
\hline \multirow[t]{4}{*}{ TRAMADOL $^{*}$} & 357,389 & EM & 189,416 & No action \\
\hline & & IM & 144,743 & Optional increase of dose \\
\hline & & PM & 17,869 & Optional increase of dose \\
\hline & & UM & 5361 & Lower dose required at start therapy \\
\hline \multirow[t]{4}{*}{ TRAMADOL AND PARACETAMOL ${ }^{*}$} & 124,951 & EM & 66,224 & No action \\
\hline & & IM & 50,605 & Optional increase of dose \\
\hline & & PM & 6248 & Optional increase of dose \\
\hline & & UM & 1874 & Lower dose required at start therapy \\
\hline \multirow[t]{4}{*}{ VENLAFAXINE } & 26,603 & EM & 14,100 & No action \\
\hline & & IM & 10,774 & $\begin{array}{l}\text { Switch to alternate drug at start } \\
\text { therapy }\end{array}$ \\
\hline & & PM & 1330 & $\begin{array}{l}\text { Switch to alternate drug at start } \\
\text { therapy }\end{array}$ \\
\hline & & UM & 399 & Optional increase of dose \\
\hline \multirow[t]{4}{*}{ ZUCLOPENTHIXOL } & 1873 & EM & 993 & No action \\
\hline & & IM & 759 & Lower dose required at start therapy \\
\hline & & PM & 94 & Lower dose required at start therapy \\
\hline & & UM & 28 & Optional increase of dose \\
\hline \multicolumn{5}{|l|}{ CYP3A5 } \\
\hline \multirow[t]{2}{*}{ TACROLIMUS ${ }^{*}$} & 2722 & Non-Ex & 2314 & No action \\
\hline & & $\begin{array}{l}\text { Het-Ex } \\
\text { Homo-Ex }\end{array}$ & $\begin{array}{l}395 \\
14\end{array}$ & $\begin{array}{l}\text { Higher dose required at start therapy } \\
\text { Higher dose required at start therapy }\end{array}$ \\
\hline
\end{tabular}


Table 2 Overview of inferred gene-drug pairs sorted per gene. An overview of the estimates of the occurrences of gene-drug pairs among 45 drugs frequently prescribed in primary care (Continued)

\begin{tabular}{|c|c|c|c|c|}
\hline Drug & $\begin{array}{l}\text { Count incident } \\
\text { prescriptions (total) }\end{array}$ & $\begin{array}{l}\text { Actionable } \\
\text { phenotype }\end{array}$ & $\begin{array}{l}\text { Count incident } \\
\text { prescriptions }\end{array}$ & $\begin{array}{l}\text { Type of therapeutic } \\
\text { recommendation }\end{array}$ \\
\hline \multicolumn{5}{|l|}{ SLCO1B1 } \\
\hline ATORVASTATIN (TOTAL) & 111,840 & & & \\
\hline \multirow{3}{*}{$\begin{array}{l}\text { ATORVASTATIN (WITHOUT CYP3A4 } \\
\text { INHIBITOR) }\end{array}$} & \multirow[t]{3}{*}{108,400} & NT (521TT) & 80,758 & No action \\
\hline & & PT (521TC) & 25,474 & Observe status of patient carefully \\
\hline & & PT (521CC) & 2168 & Observe status of patient carefully \\
\hline \multirow[t]{3}{*}{ ATORVASTATIN (WITH CYP3A4 INHIBITOR) } & \multirow[t]{3}{*}{3440} & NT (521TT) & 2563 & No action \\
\hline & & PT (521TC) & 808 & $\begin{array}{l}\text { Switch to alternate drug at start } \\
\text { therapy }\end{array}$ \\
\hline & & PT (521CC) & 69 & $\begin{array}{l}\text { Switch to alternate drug at start } \\
\text { therapy }\end{array}$ \\
\hline ATORVASTATIN AND EZETIMIBE & 1909 & & & \\
\hline \multirow{3}{*}{$\begin{array}{l}\text { ATORVASTATIN AND EZETIMIBE (WITHOUT } \\
\text { CYP3A4 INHIBITOR) }\end{array}$} & \multirow[t]{3}{*}{1739} & NT (521TT) & 1296 & No action \\
\hline & & PT (521TC) & 409 & Observe status of patient carefully \\
\hline & & PT (521CC) & 35 & Observe status of patient carefully \\
\hline \multirow{3}{*}{$\begin{array}{l}\text { ATORVASTATIN AND EZETIMIBE (WITH } \\
\text { CYP3A4 INHIBITOR) }\end{array}$} & \multirow[t]{3}{*}{170} & NT (521TT) & 127 & No action \\
\hline & & PT (521TC) & 40 & $\begin{array}{l}\text { Switch to alternate drug at start } \\
\text { therapy }\end{array}$ \\
\hline & & PT (521CC) & 3 & $\begin{array}{l}\text { Switch to alternate drug at start } \\
\text { therapy }\end{array}$ \\
\hline \multirow[t]{3}{*}{ SIMVASTATIN ${ }^{*}$} & \multirow[t]{3}{*}{187,362} & NT (521TT) & 139,585 & No action \\
\hline & & PT (521TC) & 44,030 & $\begin{array}{l}\text { Switch to alternate drug at start } \\
\text { therapy }\end{array}$ \\
\hline & & PT (521CC) & 3747 & $\begin{array}{l}\text { Switch to alternate drug at start } \\
\text { therapy }\end{array}$ \\
\hline \multirow[t]{3}{*}{ SIMVASTATIN AND EZETIMIBE* } & \multirow[t]{3}{*}{4888} & NT (521TT) & 3642 & No action \\
\hline & & PT (521TC) & 1149 & $\begin{array}{l}\text { Switch to alternate drug at start } \\
\text { therapy }\end{array}$ \\
\hline & & PT (521CC) & 98 & $\begin{array}{l}\text { Switch to alternate drug at start } \\
\text { therapy }\end{array}$ \\
\hline \multicolumn{5}{|l|}{ TPMT } \\
\hline \multirow[t]{3}{*}{ AZATHIOPRINE } & \multirow[t]{3}{*}{6943} & EM & 5867 & No action \\
\hline & & IM & 1041 & Lower dose required at start therapy \\
\hline & & PM & 35 & $\begin{array}{l}\text { Switch to alternate drug at start } \\
\text { therapy }\end{array}$ \\
\hline \multirow[t]{3}{*}{ MERCAPTOPURINE ${ }^{*}$} & \multirow[t]{3}{*}{2598} & EM & 2195 & No action \\
\hline & & IM & 390 & Lower dose required at start therapy \\
\hline & & PM & 13 & $\begin{array}{l}\text { Switch to alternate drug at start } \\
\text { therapy }\end{array}$ \\
\hline \multirow[t]{3}{*}{ TIOGUANINE } & \multirow[t]{3}{*}{1888} & EM & 1591 & No action \\
\hline & & IM & 282 & Lower dose required at start therapy \\
\hline & & PM & 9 & $\begin{array}{l}\text { Switch to alternate drug at start } \\
\text { therapy }\end{array}$ \\
\hline \multicolumn{5}{|l|}{ VKORC1 } \\
\hline \multirow[t]{2}{*}{ ACENOCOUMAROL } & \multirow[t]{2}{*}{49,934} & NS (1173CC) & 16,478 & No action \\
\hline & & NS (1173CT) & 25,217 & No action \\
\hline
\end{tabular}


Table 2 Overview of inferred gene-drug pairs sorted per gene. An overview of the estimates of the occurrences of gene-drug pairs among 45 drugs frequently prescribed in primary care (Continued)

\begin{tabular}{|c|c|c|c|c|}
\hline Drug & $\begin{array}{l}\text { Count incident } \\
\text { prescriptions (total) }\end{array}$ & $\begin{array}{l}\text { Actionable } \\
\text { phenotype }\end{array}$ & $\begin{array}{l}\text { Count incident } \\
\text { prescriptions }\end{array}$ & $\begin{array}{l}\text { Type of therapeutic } \\
\text { recommendation }\end{array}$ \\
\hline & & $\mathrm{HS}(1173 T \mathrm{~T})$ & 8239 & Lower dose required at start therapy \\
\hline \multirow[t]{3}{*}{ FENPROCOUMON } & 12,621 & NS (1173CC) & 4165 & No action \\
\hline & & NS (1173CT) & 6374 & No action \\
\hline & & HS (1173TT) & 2082 & Lower dose required at start therapy \\
\hline
\end{tabular}

"Gene-drug interactions with a recommendation both by the DPWG and CPIC

EM extensive/normal metabolizer, IM intermediate metabolizer, PM poor metabolizer, UM ultra-metabolizer, Non-Ex non-expressor, Het heterozygous expressor, HOM homozygous expressor, NT normal transport activity, PT poor transport activity, NS normal sensitivity, HS high sensitivity

conducted a sensitivity analyses for these risk factors (excluding co-medication with SLCO1B1 inhibitors) for both simvastatin and atorvastatin.

Based on the genotype frequencies inferred from the IP3 study and the SFK prescription data, out of all the first-time prescriptions for simvastatin, 44,030 individuals carried the SLCO1B1 521TC genotype (see Table 2). Using publicly available data on prevalence of relevant co-factors, we estimate that $\sim 10,000$ males with the 521TC genotype without any risk factors are present where the recommendation would be to continue therapy with $40 \mathrm{mg}$ simvastatin [31, 32]. A similar sensitivity analysis was carried out for the patients receiving simvastatin with ezetimibe. The initial analysis identified 1149 patients who would require a switch based on their inferred SLCO-1B1 521TC genotype (see Table 2). Using the same sensitivity analysis used for simvastatin, we estimate approximately 266 individuals with the 521TC genotype do not carry additional risk factors and do not require a change in therapy.

For atorvastatin, the data presented in Table 2 may be an underestimation of the trough number of switches required in clinical practice. In contrast to simvastatin, the consideration of clinical co-factors would result in additional switches. The sensitivity analysis for atorvastatin identified 6160 male patients without additional risk factors who are recommended to start atorvastatin with the normal dose from the total 27,642 patients with 521TC and CC genotypes. In contrast, in a group of $\sim 21,000$ patients, atorvastatin should be switched to an alternate therapy due to the existence additional risk factors identified by the DPWG. A similar analysis for the combination of atorvastatin with ezetimibe shows 83 patients with the 521TC or CC genotype without risk factors who can start therapy with the ezetimibe/atorvastatin combination, while in 289 patients with these genotypes additional risk factors are present likely resulting in a switch to an alternate cholesterol-lowering therapy. Overall, the results of both our sensitivity analysis indicate that without accounting for additional clinical factors for the gene-drug interactions concerning SCLO1B1, our estimates of 195,691 patients requiring an intervention is conservative and could be as high as $\sim 206,981$.

Additionally, due to the structure of the obtained prescription data, the analysis in this study was performed from the perspective of prescriptions within the time frame of a year. The IP3 study (used for this analysis) and multiple other studies using panel-based pharmacogenetic testing show that patients often carry multiple actionable pharmacogenes [17-19, 24]. In reality, physicians and pharmacists will thus likely encounter multiple actionable phenotypes in the same patient and due to polypharmacy are likely to encounter multiple gene-drug interactions in each patient [33]. Additional follow-up of the IP3 study indeed showed that within 2.5-year follow-up, $97 \%$ of the included patients received a prescription for a newly initiated drug with an actionable DGI, while $33 \%$ of the patients received up to four new prescriptions with known gene-drug interactions. In the newly started prescriptions in our cohort, $24.2 \%$ of the patients indeed carried the actionable phenotype, requiring an intervention by the pharmacist [34]. These data show that an increase in the studied timeframe will show a larger impact on healthcare. However, our results indicate that pre-emptive PGx testing for a panel of eight genes can already have significant impact on first prescriptions within the timeframe of a single year. Results of such a PGx test can be re-used over the entire lifespan of an individual. It is highly likely that impact will be even larger in reality as $13.5 \%$ of the patients that visit (Dutch) community pharmacies use $\geq 5$ drugs from different ATC3 classes [26]. Moreover, due to the increase in the proportion of elderly ( $\geq 65$ years), the number of polypharmacy patients will likely increase in the future, increasing the possible impact of a pharmacogenomics panel [26].

As a result of the use of a PGx panel with a limited number of pharmacogenes, this may lead to an underestimate of the potential impact of PGx in primary care in The Netherlands. After the initiation of the IP3 pilot 


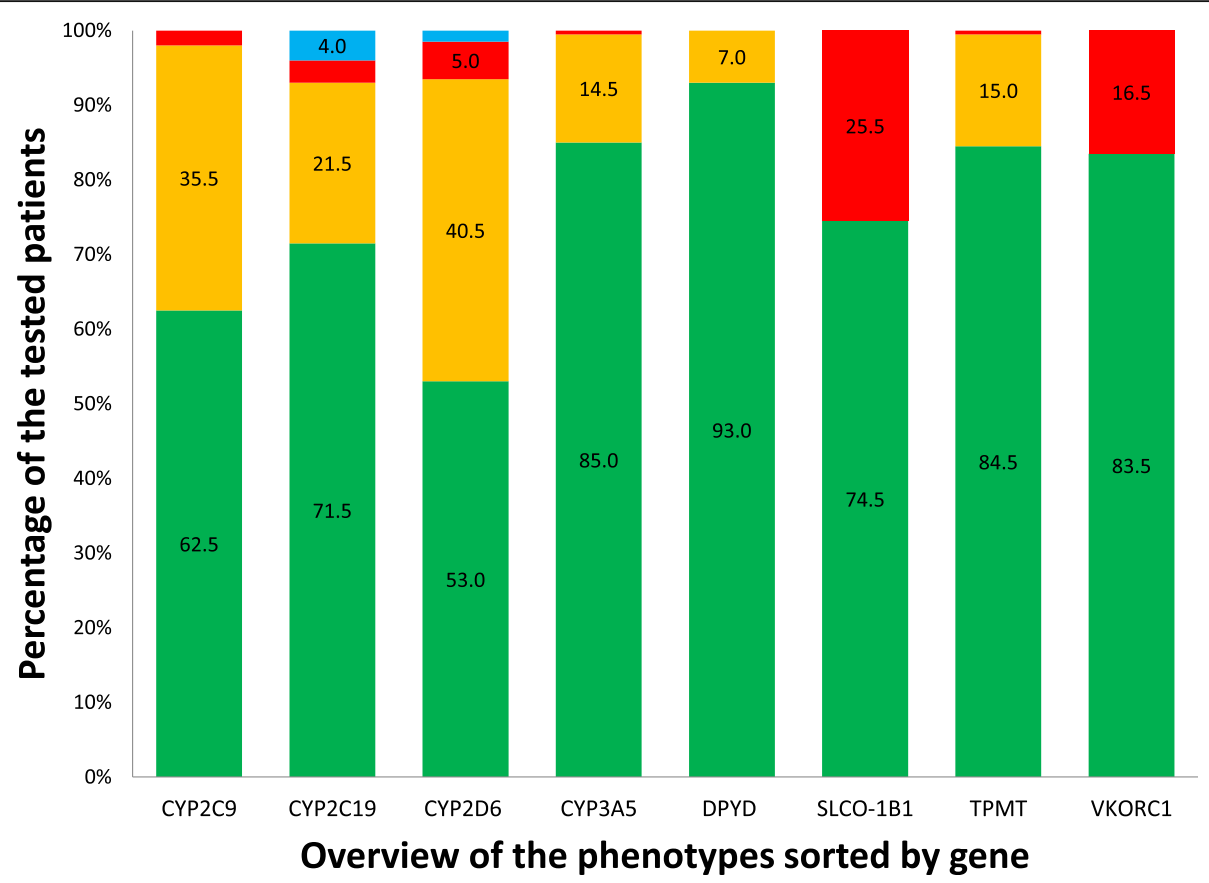

Fig. 1 An overview of the genotype predicted phenotypes observed in the IP3 pilot study. Green: extensive/normal metabolizer (CYP2C9, CYP2C19, CYP2D6, DPYD \& TPMT) / non-expressor (CYP3A5) / normal transporter activity (SLCO1B1) / normal sensitivity (VKORC1). Orange: intermediate metabolizer (CYP2C9, CYP2C19, CYP2D6, DPYD \& TPMT) / heterozygous expressor (CYP3A5). Red: poor metabolizer (CYP2C9, CYP2C19, CYP2D6, DPYD \& TPMT) / homozygous expressor (CYP3A5) / poor transporter activity (SLCO1B1) / high sensitivity (VKORC1). Blue: ultra-rapid metabolizer (CYP2C19 \& CYP2D6) (see Additional file 1 for an overview of the tested variants)

study, the DPWG has published additional guidelines on gene-drug pairs other than $C Y P 2 C 9, C Y P 2 C 19, C Y P 2 D 6$, CYP3A5, DPYD, SLCO1B1, TPMT, and VKORC1 existing on the DMET micro-array platform but not included in this panel (e.g., CYP1A2, CYP2B6, and UGT1A1) [24]. In addition, the chosen platform in the pilot study does not encompass all genes deemed relevant by the DPWG such as FVL and HLA genes. Of note, this study only encompasses interventions based on therapeutic recommendations for gene-drug interactions described in the guidelines of the DPWG as they are incorporated in the clinical decision support systems of healthcare professionals in The Netherlands. In clinical practice, the Dutch clinicians will thus most likely only use the therapeutic recommendations by the DPWG. In countries where the guidelines of the CPIC are used to guide pharmacotherapy, the number of prescriptions with a combination of actionable phenotypes and associated drugs will likely differ somewhat as the DPWG has provided therapeutic recommendations for certain gene-drug interactions that are not covered by CPIC and vice versa. However, a recent systematic comparison of the guidelines of the CPIC and the DPWG found that a selection of 27 well-known gene-drug interactions (all included in the selection of this study) was covered by both consortia and the two consortia provided similar therapeutic recommendations for these gene-drug interactions [7].
Similar to the Ubiquitous Pharmacogenomics (U-PGx) project, current genotyping initiatives using a pre-emptive panel approach should use a platform which provides an extensive panel and is flexible (such as the QuantStudio 12K Flex Real-Time PCR System by Thermo Fisher Scientific or the SNPline by LGC Group) to allow for adjusting if new guidelines are published by CPIC or the DPWG [35].

Currently, the implementation of PGx in primary care remains low in The Netherlands as shown by a recent survey among Dutch pharmacists that showed 14.7\% adoption of PGx testing, despite the existence of guidelines containing therapeutic recommendations and their integration into the workflow of healthcare professionals [5, 6, 36]. In part, this may be explained by the fact that not all healthcare professionals are aware of the existence of clinical decision support in electronic medication surveillance systems. A recent survey among pharmacists showed that $65.4 \%$ were aware that clinical decision support contained therapeutic recommendations for genetic predicted phenotypes [36]. The potential of PGx has grown, but probably other healthcare professionals (such as physicians) are less aware of the state in which PGx is already available in their workflow. Finally, the clinical utility and cost-effectiveness of pre-emptive panel-based screening for PGx variants has only been shown in small pilot studies, but large clinical trials providing the required evidence are still lacking [20-22]. Initiatives such as the U-PGx, a multinational consortium 
implementing a model of pre-emptive PGx-testing in healthcare environments in seven European nations, will investigate whether upfront implementation of a panelbased pharmacogenetic screening can lead to better patient outcomes in a cost-effective manner [35].

\section{Conclusions}

Based on the data presented in this study, it can be concluded that an actionable gene-drug interaction is present in approximately one out of four new prescriptions for a drug classified by the DPWG guidelines as requiring therapeutic intervention. Should all patients with a new prescription for this selection of drugs have been pre-emptively genotyped, 1 out of every 19 new prescriptions could have been adjusted based on the genetic test result. Consequently, with an anticipated near future where healthcare professionals will be confronted with results of PGx panels, adjusting pharmacotherapy as a result of relevant gene-drug interaction will likely become a routine task in drug prescribing.

\section{Additional file}

Additional file 1: Overview of tested PGx variants. Description of data: An overview of the PGx variants included in the panel used in the Implementation of Pharmacogenetics into Primary Care Project (IP3) study. (DOCX 16 kb)

\section{Acknowledgements}

We would like to thank F. van Tienen for his assistance in the data analysis of this study.

\section{Funding}

This work was supported by unrestricted grants from The Royal Dutch Pharmacist's Association, The Hague (KNMP), The Netherlands, and Zorg \& Zekerheid, Leiden, The Netherlands.

\section{Availability of data and materials}

The dataset generated in the IP3 study are available in the Leiden Open (source) Variation Database.

\section{Authors' contributions}

$P B$, JS, and HJG designed the research. PB performed the research. PB and JS analyzed the data. PB, JS and HJG wrote the manuscript. All authors read and approved the final manuscript.

\section{Ethics approval and consent to participate}

The central Medical Ethics Review board of the Leiden University Medical Center (LUMC) in Leiden, The Netherlands, approved the protocol of the IP3 study.

\section{Consent for publication}

Not applicable.

\section{Competing interests}

The authors declare that they have no competing interests.

\section{Publisher's Note}

Springer Nature remains neutral with regard to jurisdictional claims in published maps and institutional affiliations.
Received: 2 December 2018 Accepted: 8 May 2019

Published online: 14 June 2019

\section{References}

1. Leendertse AJ, Egberts AC, Stoker LJ, van den Bemt PM. Frequency of and risk factors for preventable medication-related hospital admissions in the Netherlands. Arch Intern Med. 2008;168(17):1890-6.

2. Spear BB, Heath-Chiozzi M, Huff J. Clinical application of pharmacogenetics. Trends Mol Med. 2001:7(5):201-4.

3. Huang SM, Temple R. Is this the drug or dose for you? Impact and consideration of ethnic factors in global drug development, regulatory review, and clinical practice. Clin Pharmacol Ther. 2008;84(3):287-94.

4. Bank PC, Swen JJ, Guchelaar HJ. Pharmacogenetic biomarkers for predicting drug response. Expert Rev Mol Diagn. 2014;14(6):723-35.

5. Swen JJ, Nijenhuis M, de Boer A, Grandia L, Maitland-van der Zee AH, Mulder H, Rongen GA, van Schaik RH, Schalekamp T, Touw DJ, et al. Pharmacogenetics: from bench to byte--an update of guidelines. Clin Pharmacol Ther. 2011;89(5):662-73.

6. Swen JJ, Wilting I, de Goede AL, Grandia L, Mulder H, Touw DJ, de BA Conemans JM, Egberts TC, Klungel OH, et al. Pharmacogenetics: from bench to byte. Clin Pharmacol Ther. 2008;83(5):781-7.

7. Bank PC, Caudle KE, Swen J, Gammal RS, Whirl-Carrillo M, Klein TE, Relling MV Guchelaar HJ. Comparison of the guidelines of the Clinical Pharmacogenetics Implementation Consortium and the Dutch Pharmacogenetics Working Group. Clin Pharmacol Ther. 2018;103(4):599-618.

8. Lunenburg CA, van Staveren MC, Gelderblom H, Guchelaar HJ, Swen JJ. Evaluation of clinical implementation of prospective DPYD genotyping in 5fluorouracil- or capecitabine-treated patients. Pharmacogenomics. 2016; 17(7):721-9.

9. Deenen MJ, Meulendijks D, Cats A, Sechterberger MK, Severens $J L$, Boot $H$, Smits PH, Rosing H, Mandigers CM, Soesan M, et al. Upfront genotyping of DPYD*2A to individualize fluoropyrimidine therapy: a safety and cost analysis. J Clin Oncol. 2016:34(3):227-34.

10. Henricks LM, Lunenburg C, de Man FM, Meulendijks D, Frederix GWJ, Kienhuis E, Creemers GJ, Baars A, Dezentje VO, ALT I, et al. DPYD genotypeguided dose individualisation of fluoropyrimidine therapy in patients with cancer: a prospective safety analysis. Lancet Oncol. 2018;19(11):1459-67.

11. Hoffman JM, Haidar CE, Wilkinson MR, Crews KR, Baker DK, Kornegay NM, Yang W, Pui CH, Reiss UM, Gaur AH, et al. PG4KDS: a model for the clinical implementation of pre-emptive pharmacogenetics. Am J Med Genet C Semin Med Genet. 2014;166C(1):45-55.

12. van Driest SL, Shi Y, Bowton EA, Schildcrout JS, Peterson JF, Pulley J, Denny JC, Roden DM. Clinically actionable genotypes among 10,000 patients with preemptive pharmacogenomic testing. Clin Pharmacol Ther. 2014;95(4):423-31.

13. O'Donnell PH, Bush A, Spitz J, Danahey K, Saner D, Das S, Cox NJ, Ratain MJ. The 1200 patients project: creating a new medical model system for clinical implementation of pharmacogenomics. Clin Pharmacol Ther. 2012;92(4):446-9.

14. O'Donnell PH, Danahey K, Jacobs M, Wadhwa NR, Yuen S, Bush A, Sacro Y, Sorrentino MJ, Siegler M, Harper W, et al. Adoption of a clinical pharmacogenomics implementation program during outpatient care--initial results of the University of Chicago "1,200 Patients Project". Am J Med Genet C Semin Med Genet. 2014;166C(1):68-75.

15. Bielinski SJ, Olson JE, Pathak J, Weinshilboum RM, Wang L, Lyke KJ, Ryu E, Targonski PV, Van Norstrand MD, Hathcock MA, et al. Preemptive genotyping for personalized medicine: design of the right drug, right dose, right time-using genomic data to individualize treatment protocol. Mayo Clin Proc. 2014;89(1):25-33.

16. Johnson JA, Elsey AR, Clare-Salzler MJ, Nessl D, Conlon M, Nelson DR. Institutional profile: University of Florida and Shands Hospital Personalized Medicine Program: clinical implementation of pharmacogenetics. Pharmacogenomics. 2013;14(7):723-6.

17. Dunnenberger HM, Crews KR, Hoffman JM, Caudle KE, Broeckel U, Howard SC, Hunkler RJ, Klein TE, Evans WE, Relling MV. Preemptive clinical pharmacogenetics implementation: current programs in five US medical centers. Annu Rev Pharmacol Toxicol. 2015;55:89-106.

18. Bush WS, Crosslin DR, Owusu-Obeng A, Wallace J, Almoguera B, Basford MA Bielinski SJ, Carrell DS, Connolly JJ, Crawford D, et al. Genetic variation among 82 pharmacogenes: the PGRNseq data from the eMERGE network Clin Pharmacol Ther. 2016;100(2):160-9.

19. Ji Y, Skierka JM, Blommel JH, Moore BE, VanCuyk DL, Bruflat JK, Peterson LM, Veldhuizen TL, Fadra N, Peterson SE, et al. Preemptive pharmacogenomic 
testing for precision medicine: a comprehensive analysis of five actionable pharmacogenomic genes using next-generation DNA sequencing and a customized CYP2D6 genotyping cascade. J Mol Diagn. 2016;18(3):438-45.

20. Brixner D, Biltaji E, Bress A, Unni S, Ye X, Mamiya T, Ashcraft K, Biskupiak J. The effect of pharmacogenetic profiling with a clinical decision support tool on healthcare resource utilization and estimated costs in the elderly exposed to polypharmacy. J Med Econ. 2016;19(3):213-28.

21. Elliott LS, Henderson JC, Neradilek MB, Moyer NA, Ashcraft KC, Thirumaran RK. Clinical impact of pharmacogenetic profiling with a clinical decision support tool in polypharmacy home health patients: a prospective pilot randomized controlled trial. PLoS One. 2017;12(2):e0170905.

22. Finkelstein J, Friedman C, Hripcsak G, Cabrera M. Pharmacogenetic polymorphism as an independent risk factor for frequent hospitalizations in older adults with polypharmacy: a pilot study. Pharmacogenomics Pers Med. 2016;9:107-16

23. Kantor ED, Rehm CD, Haas JS, Chan AT, Giovannucci EL. Trends in prescription drug use among adults in the United States from 1999-2012. J Am Med Assoc. 2015;314(17):1818-31.

24. Bank PC, Swen JJ, Schaap RD, Klootwijk DB, Baak-Pablo RF, Guchelaar HJ: A pilot study of the implementation of pharmacogenomic pharmacist initiated pre-emptive testing in primary care. EJHG. 2019: accepted.

25. Geneesmiddel Informatie Centrum: Informatorium Medicamentorum. The Hague: Knmp Medicijn Media; 2017.

26. Griens AMGF, Kroon JDL, Lukaart JS, Van der Vaart RJ. Data en feiten 2018. The Hague: The Dutch Foundation fro Pharmaceutical Statistics; 2019.

27. Gaedigk A, Sangkuhl K, Whirl-Carrillo M, Klein T, Leeder JS. Prediction of CYP2D6 phenotype from genotype across world populations. Genet Med. 2017;19(1):69-76.

28. Genome of the Netherlands Consortium. Whole-genome sequence variation, population structure and demographic history of the Dutch population. Nature genetics 2014;46(8):818-25

29. Lek M, Karczewski KJ, Minikel EV, Samocha KE, Banks E, Fennell T, O'DonnellLuria AH, Ware JS, Hill AJ, Cummings BB, et al. Analysis of protein-coding genetic variation in 60,706 humans. Nature. 2016;536(7616):285-91.

30. Samwald M, Xu H, Blagec K, Empey PE, Malone DC, Ahmed SM, Ryan P, Hofer S, Boyce RD. Incidence of exposure of patients in the United States to multiple drugs for which pharmacogenomic quidelines are available. PLoS One. 2016;11(10):e0164972.

31. Donker GA. Continue Morbiditeits Registratie peilstations Nederland 2008. Utrecht: Nederlands instituut voor onderzoek van de gezondheidszorg (NIVEL); 2008.

32. Fleming D, Schellevis FG, van der Linden M, Westert GP. A comparison of disease prevalence in general practice in the Netherlands and in England Wales. In: Morbidity, performance and quality in primary care. Oxford: Raddiffe; 2006.

33. O'Donnell PH, Danahey K, Ratain MJ. The outlier in all of us: why implementing pharmacogenomics could matter for everyone. Clin Pharmacol Ther. 2016;99(4):401-4.

34. van der Wouden CH, Bank PC, Özokcu K, Swen JJ, Guchelaar HJ: PharmacistInitiated Pre-Emptive Pharmacogenetic Panel Testing with Clinical Decision Support in Primary Care: Record of PGx Results and Real-World Impact. Accepted 2019.

35. van der Wouden $\mathrm{CH}$, Cambon-Thomsen A, Cecchin E, Cheung KC, Lucia Davila-Fajardo C, Deneer VH, Dolzan V, Ingelman-Sundberg M, Jonsson S, Karlsson MO, et al. Implementing pharmacogenomics in Europe: design and implementation strategy of the ubiquitous pharmacogenomics consortium. Clin Pharmacol Ther. 2017;101(3):341-58.

36. Bank PC, Swen JJ, Guchelaar HJ. A nationwide survey of pharmacists' perception of pharmacogenetics in the context of a clinical decision support system containing pharmacogenetics dosing recommendations. Pharmacogenomics. 2017;18(3):215-25.

Ready to submit your research? Choose BMC and benefit from:

- fast, convenient online submission

- thorough peer review by experienced researchers in your field

- rapid publication on acceptance

- support for research data, including large and complex data types

- gold Open Access which fosters wider collaboration and increased citations

- maximum visibility for your research: over $100 \mathrm{M}$ website views per year

At BMC, research is always in progress.

Learn more biomedcentral.com/submissions 